\title{
Urinary Polypeptides Related to Collagen Synthesis
}

\author{
Stephen M. Krane, Alberto J. Muñoz, and Edward D. Harris, Jr. \\ From the Departments of Medicine, Harvard Medical School, and the \\ Massachusetts General Hospital, Boston, Massachusetts 02114
}

A B S T R A C T Of the total urinary hydroxyproline in normal subjects and those with skeletal disorders, between 4 and $20 \%$ was nondialyzable. In some patients with Paget's disease of bone, hyperparathyroidism with osteitis fibrosa, hyperphosphatasia, and extensive fibrous dysplasia the total urinary hydroxyproline was sufficiently high to permit purification of this polypeptide hydroxyproline by gel filtration and ion exchange chromatography. The partially purified polypeptides had molecular weights between 4500 and 10,000 and amino acid compositions and physical properties resembling those of gelatin. The polypeptide fractions also contained neutral sugar and glucosamine. These fragments had been shown to be susceptible to cleavage by purified bacterial collagenase suggesting the presence of the sequence -Pro-X-Gly-Pro-Y-.

After administration of proline $-{ }^{14} \mathrm{C}$ to patients with Paget's disease hydroxyproline $-{ }^{14} \mathrm{C}$ was excreted in the urine. The hydroxyproline $-{ }^{14} \mathrm{C}$ specific activity reached a peak in $2-4 \mathrm{hr}$ and declined rapidly. The specific activity of the polypeptide (retentate) portion was severalfold greater than that of the raw urine and diffusate. When the labeled urines were subjected to gel filtration the hydroxyproline $-{ }^{14} \mathrm{C}$ fractions of highest molecular weight which were eluted first from the columns had the highest specific activities. Exposure of the hydroxyproline $-{ }^{14} \mathrm{C}$-containing polypeptides to bacterial collagenase rendered them dialyzable.

Four patients with hyperparathyroidism and osteitis fibrosa were studied before and after removal of a parathyroid adenoma, a period of transition from a predominance of bone collagen resorption to one of relatively increased bone collagen synthesis. The total urinary hydroxyproline fell rapidly after operation whereas the ratio of the polypeptide fraction to the total rose three- to fourfold. The results of these studies suggest that the urinary polypeptides represent frag-

Dr. Muñoz was a Fellow of the International Atomic Energy Commission. Dr. Harris was a Special Post Doctoral Fellow of the National Institute of Arthritis and Metabolic Diseases.

Received for publication 24 September 1969. ments of collagen related to collagen synthesis. Changes in the ratio of these peptides to total hydroxyproline in the urine may serve as an index of new bone formation in patients with skeletal disorders.

\section{INTRODUCTION}

Collagen is the most abundant extracellular protein in mammalian tissues and is the major component of the organic matrix of bone (1). As bone is remodeled the collagen is resorbed and resynthesized, and the rate of its turnover in adults may be greater than that of collagen in other tissues such as skin and tendon (2). Since hydroxyproline is an amino acid present almost exclusively in collagen and is not reutilized for the synthesis of collagen, the urinary excretion of free and peptidebound hydroxyproline has been assumed to reflect the metabolism of this protein (3). Hydroxylysine is another amino acid present almost exclusively in collagen and the rate of urinary excretion of peptides containing hydroxylysine also has been suggested to reflect collagen metabolism $(4,5)$.

The results of studies utilizing radioisotopically labeled proline (the precursor of collagen hydroxyproline) which compare the specific activities of hydroxyproline in urinary peptides and collagens of the tissues of the rat have suggested that a large part of the urinary hydroxyproline is derived from the breakdown of mature collagen $(6,7)$. In man it has been shown by Meilman, Urivetsky, and Rapoport (8) that almost all of the urinary hydroxyproline is present as di- and tripeptides containing proline and glycine. The fact that the peptide Gly-Pro-Hypro, ${ }^{1}$ a triplet which occurs commonly in collagen, was identified provided further evidence for the relationship of these urinary peptides to collagen.

However, the presence of hydroxyproline in a small peptide is not in itself sufficient to relate it to collagen.

\footnotetext{
${ }^{1}$ Abbreviations are as follows: Gly = glycine; Pro $=$ proline; Hypro = hydroxyproline. Unless otherwise specified hydroxyproline refers to 4-hydroxyproline.
} 
The latter is a complex triple-helical molecule which has distinctive physical and chemical properties. This study was therefore initiated (9) in an attempt to identify in human urine hydroxyproline-containing peptides of high enough molecular weight to have chemical properties more closely resembling the collagen macromolecule in order to provide stronger evidence linking their origin to collagen itself and to provide an additional index of the turnover of the protein.

Hydroxyproline-containing glycopeptides of estimated molecular weight 1500 had been identified by Bourrillon and Vernay (10) in normal human urine and somewhat larger glycopeptides were found in the urine of patients with sprue by Cherian and Radhakrishnan (11). We initially examined the urine of patients with Paget's disease of bone for hydroxyproline-containing polypeptides (9) since it has been shown that such individuals excreted large amounts of bound hydroxyproline (12) and the rate of excretion correlated reasonably well with the rate of bone remodeling (13). We found that pagetic subjects excreted urinary polypeptides which had the amino acid composition and other properties resembling those of fragments of collagen. Preliminary evidence obtained using isotope incorporation into the hydroxyproline of these peptides suggested that they were related to collagen synthesis (9). In the present report these observations have been extended to include patients with osteitis fibrosa generalisata of hyperparathyroidism as well as other disorders of bone. The findings provide additional evidence that the excretion of urinary polypeptides containing hydroxyproline is related to collagen synthesis.

\section{METHODS}

All subjects were maintained on gelatin-free diets. Specimens of urine were collected under toluene at $2^{\circ}-5^{\circ} \mathrm{C}$ for $24-\mathrm{hr}$ periods and then filtered and stored at $-20^{\circ} \mathrm{C}$.

11 patients (age range 47-76) with characteristic clinical and roentgenological features of Paget's disease of bone were studied. The level of alkaline phosphatase in the serum ranged from 10 to 89 Bodansky units. Urine specimens were also obtained from an $18 \mathrm{yr}$ old girl with extensive polyostotic fibrous dysplasia (alkaline phosphatase 35 Bodansky units), a $19 \mathrm{yr}$ old girl with hyperphosphatasia (case 2, reference 14, alkaline phosphatase ranged from 111 to 400 King-Armstrong units), and three normal adult males.

Four subjects (age range 46-66) had typical hyperparathyroidism and osteitis fibrosa generalisata. None had significant renal dysfunction. Samples of urine were collected before and for 5-7 days after successful treatment of the hyperparathyroidism by the surgical removal, in each instance, of a single adenoma of one parathyroid gland. Each of these subjects had increased alkaline phosphatase in the serum (range 14-31 Bodansky units). Three patients had roentgenological signs of subperiosteal resorption typical of osteitis fibrosa and the remaining subject had a lytic lesion of the right femur without subperiosteal resorption.

Analytical procedures. Hydroxyproline was determined chemically in unpurified samples by the method of Prockop and Udenfriend (15) and in partially purified samples by the method of Bergman and Loxley (16) and on the automatic amino acid analyzer. For amino acid analysis, hydrolysis was performed in sealed glass tubes or tubes with a Teflon cap, in triply distilled constant boiling $\mathrm{HCl}(5.7$ $\mathrm{N}$ ) in an atmosphere of nitrogen at $105^{\circ} \mathrm{C}$ for $18-24 \mathrm{hr}$. Amino acid analyses were performed using modified commercial models (Phoenix Precision Instruments and Beckman Instruments) of the automatic amino acid analyzer by the single-column method of Piez and Morris (17). No corrections were made for destruction of amino acids during hydrolysis.

Protein was measured by the procedure of Lowry, Rosebrough, Farr, and Randall (18) and was monitored during chromatography by absorbance at 230 and $280 \mathrm{~m} \mu$. Cytochrome $c$ used to mark columns for gel filtration was measured by absorbance at $550 \mathrm{~m} \mu$.

Clostridial collagenase obtained from Worthington Biochemicals was further purified by the method of Seifter, Gallop, Klein, and Meilman (19).

After acid hydrolysis hexoses were chromatographed descending on Whatman No. 1 filter paper using $n$-butanolethanol-water $(10: 1: 2)$ (20) and quantitated after elution by the method of Park and Johnson (21). Hexosamine determinations were performed by the Elson-Morgan reaction (22). Quantitative analysis of carbohydrates also was performed by methanolysis, derivativization and gas-liquid chromatography by the method of Reinhold and Jeanloz."

Molecular weights of selected partially purified polypeptides were estimated by high-speed equilibrium sedimentation (23). Details are given in the Appendix.

Separation and purification of polypeptides containing hydroxyproline. Variable amounts of filtered urine were dialyzed for $5-7$ days at $2^{\circ}-5^{\circ} \mathrm{C}$ against approximately 40 50 volumes of $0.15 \mathrm{M} \mathrm{NaCl}$ followed by at least three changes of similar volumes of distilled water, and the retentate was freeze-dried. When larger volumes were processed some samples were ultrafiltered before dialysis using an Amicon Chamber with a UM-1 Diaflo membrane. Aliquot portions of the freeze-dried material $(100-800 \mathrm{mg}$ dry weight) were then suspended in $15-25 \mathrm{ml}$ of the denaturing solvent $5 \mathrm{M} \mathrm{LiCl}$ (24) buffered with $0.01 \mathrm{M}$ Tris$\mathrm{HCl}, \mathrm{pH}$ 7.4. Essentially all of the hydroxyproline-containing substances were soluble and the insoluble material was centrifuged down at $3000 \mathrm{rpm}$ and discarded. The supernatant solution was then applied to columns (usual dimensions $125 \times 3 \mathrm{~cm}$ ) of Sephadex G-75 (Pharmacia Fine Chemicals) and eluted with the same buffer. The fractions containing hydroxyproline were pooled and desalted by dialysis against distilled water or by gel filtration on columns (usual dimensions $73 \times 2.5 \mathrm{~cm}$ ) of Bio-Gel P-6 (BioRad Laboratories), equilibrated, and eluted with $0.1 \mathrm{M}$ acetic acid.

Fractions containing hydroxyproline were further purified by ion exchange chromatography. Anion exchange chromatography was performed on columns $(1 \times 9 \mathrm{~cm})$ of diethylaminoethyl (DEAE) cellulose using Cellex D (Bio-Rad Laboratories) and DE 52 ( $\mathrm{H}$. Reeve Angel \& Co.). Samples were applied in $0.01 \mathrm{M}$ Tris- $\mathrm{HCl}, \mathrm{pH} 8.2$, at room temperature and eluted with the same buffer followed by a linear gradient of $0.4 \mathrm{M} \mathrm{NaCl}$ in the same buffer; of this solvent $250 \mathrm{ml}$ was in the reservoir and $250 \mathrm{ml}$ of buffer was in the mixing chamber.

For cation exchange chromatography, columns $(2.5 \times 18$ $\mathrm{cm}$ ) of phosphocellulose (Reeve Angel) were prepared and

\footnotetext{
${ }^{2}$ Reinhold, V., and R. W. Jeanloz. In preparation.
} 
equilibrated with $0.001 \mathrm{M}$ ammonium formate, $\mathrm{pH} 3.6$ (25). Samples from the columns of Sephadex G-75 containing hydroxyproline were dissolved in this buffer at $40^{\circ} \mathrm{C}$, applied to these columns, and eluted with a linear gradient of 0.6 $\mathbf{M ~} \mathrm{NaCl}$ in the same buffer using a reservoir of $800 \mathrm{ml}$ and a mixing chamber of $800 \mathrm{ml}$. Conductivity expressed as reciprocal milliohms (mmhos) was determined using a meter from Industrial Instruments, Inc.

Quantitation of polypeptide-hydroxyproline in urine samples. The amount of polypeptide hydroxyproline was assayed in individual samples by two methods. In the first method, polypeptide hydroxyproline was separated from oligopeptide hydroxyproline by dialysis. Samples of urine, usually $10 \mathrm{ml}$, were placed in dialysis sacs ( 16 inch) which were then dialyzed against approximately 50 volumes of $0.15 \mathrm{M} \mathrm{NaCl}$ and three changes of similar volumes of dis- tilled water for a total period of $72 \mathrm{hr}$. The content of hydroxyproline remaining in the sac (retentate) was then compared with that of the same sample before dialysis; correction was made for any change in volume.

A second method was based on our observation that the major portion of the polypeptide hydroxyproline emerged from columns of Bio-Gel P-6 with the cytochrome $c$ marker (9). Therefore, samples of untreated urine $(5 \mathrm{ml})$ plus $10 \mathrm{mg}$ of cytochrome $c$ were passed through columns (26 $\times 2.5 \mathrm{~cm}$ ) of Bio-Gel P-6 using $0.1 \mathrm{M}$ acetic acid as eluting solvent. Fractions containing cytochrome $c$ emerging from the column were monitored by absorbance at $550 \mathrm{~m} \mu$, pooled, taken to dryness using a rotary evaporator at $55^{\circ} \mathrm{C}$ (Buchler Instruments, Inc., Fort Lee, N. J.), hydrolyzed in $\mathrm{HCl}$, and analyzed for hydroxyproline (15).

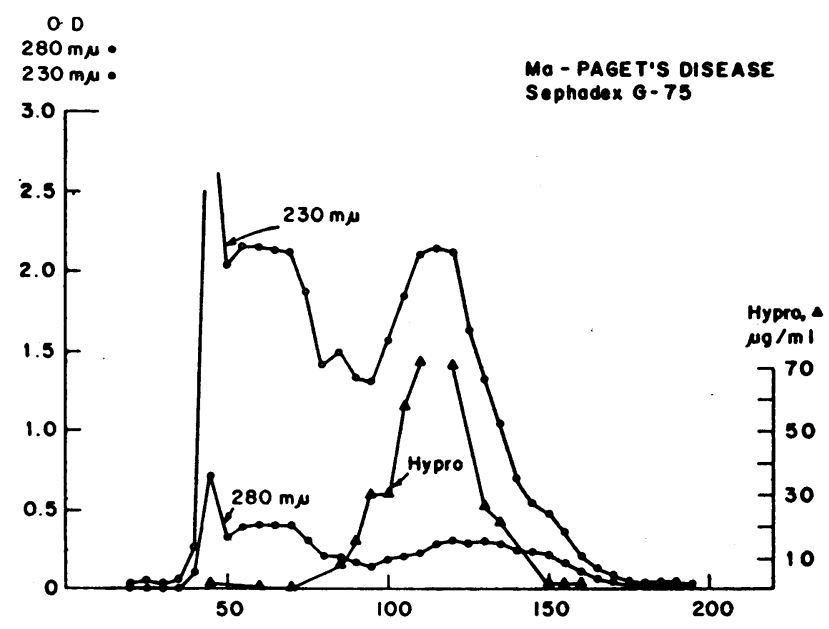

FRACTION NUMBER

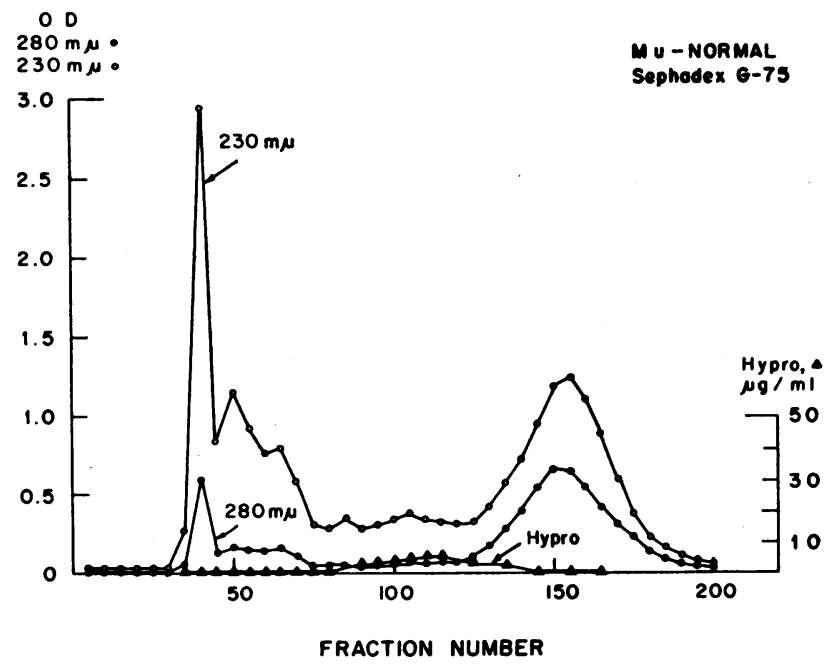

Figure 1 Gel filtration on column of Sephadex G-75 of urinary retentate from a patient with Paget's disease (upper) and a normal male subject (lower). Dimensions of column were $125 \times 3 \mathrm{~cm}$. Fractions of approximately $6 \mathrm{ml}$ were collected. For further details see text. 


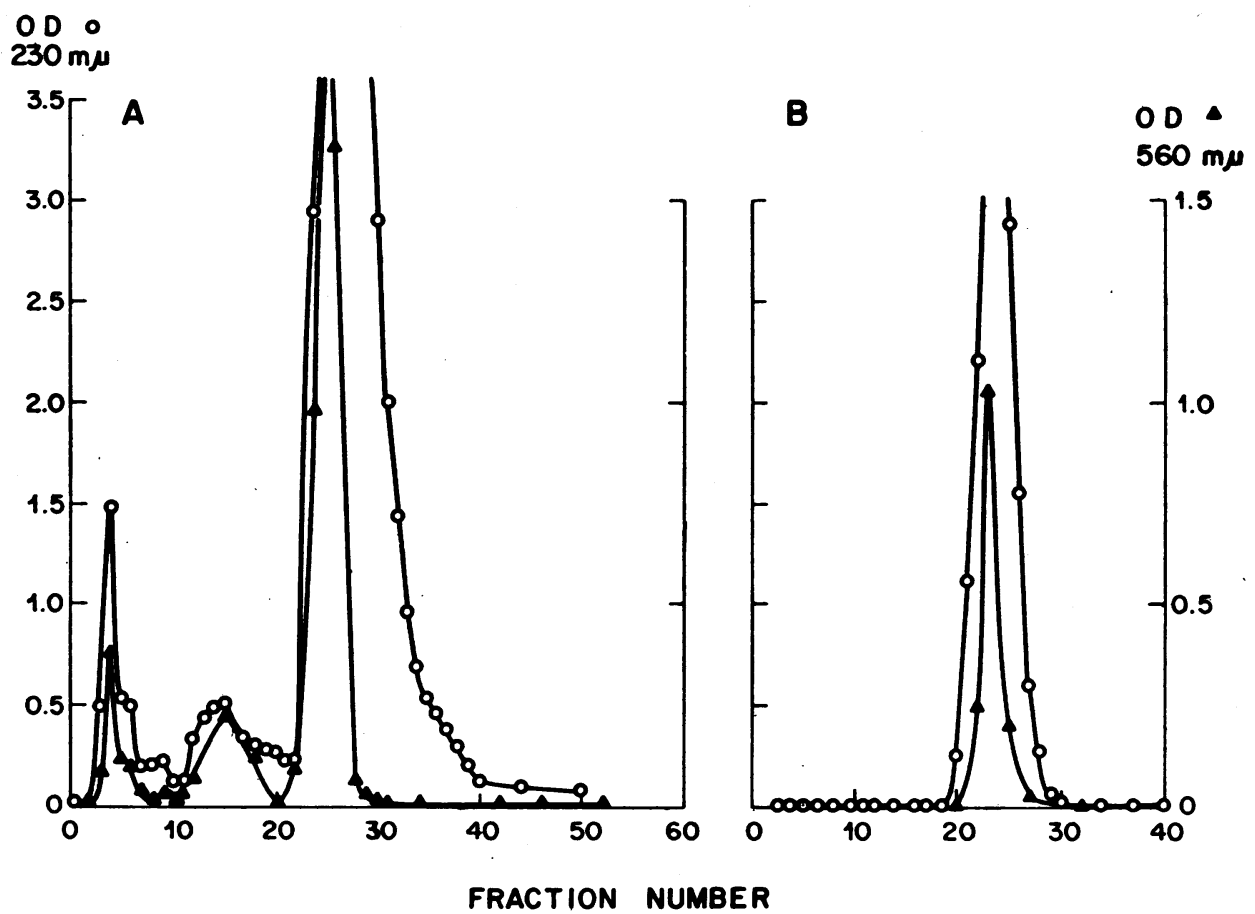

FIGURE 2 Ion exchange chromatography on DEAE-cellulose of urinary hydroxyprolinecontaining polypeptide from a patient with Paget's disease ( $\mathrm{Sa}$, Table I) after initial gel filtration on Sephadex G-75. Each fraction was $2 \mathrm{ml}$. A. Initial chromatography. The salt gradient was initiated at fraction number 21. B. Rechromatography of pool of fractions 24-27 after desalting on Bio-Gel P-6. Salt gradient was initiated at fraction No. 16.

Isotope studies. One patient with Paget's disease was given an oral dose of proline ${ }^{14} \mathrm{C}(250 \mu \mathrm{Ci})$ as the labeled precursor of hydroxyproline. Samples of urine were dialyzed as described above for 1 or $2 \mathrm{hr}$ against equal volumes of water to obtain dialyzable fractions representing small peptides (diffusate). The dialysis sacs were then suspended in $40-50$ volumes of water and dialyzed against three to four changes for $48-72 \mathrm{hr}$ to remove any remaining low molecular weight hydroxyproline peptides. Specific activity of the hydroxyproline ${ }^{14} \mathrm{C}$ in the retentate, diffusate, and untreated urine was then determined in acid hydrolysates by modifications of the methods of LeRoy, Harris, and Sjoerdsma (26) and Juva and Prockop (27). These methods were designed specifically for the assay of small amounts of hydroxyproline $-{ }^{14} \mathrm{C}$ in the presence of a large excess of proline $-{ }^{14} \mathrm{C}$ and other radioactivity not attributable to hydroxyproline.

Total activity in urine was measured by counting an aliquot portion using Bray's solution (28) as fluorophor. Samples of plasma were deproteinated with $5 \%$ trichloroacetic acid (final concentration), centrifuged, and assayed by counting aliquot portions of the supernatant solution. Total expired air was collected for precisely measured intervals, and estimations of the ${ }^{14} \mathrm{CO}_{2}$ evolved were made using the method of Rabkin, Frederick, Lotz, and Smith (29).

\section{RESULTS}

Of the total hydroxyproline excreted in the urine over the $24 \mathrm{hr}$ period, between 4 and $21 \%$ was nondialyzable using the procedure described. Subjects with Paget's disease excreted between 5 and $10 \%$ of the urinary hydroxyproline in the nondialyzable fraction (retentate).

Typical elution patterns from columns of Sephadex G-75 of the retentates corresponding to one patient with Paget's disease and a normal control, respectively, are shown in Fig. 1. The amount applied to the column represented the nondialyzable material in $53 \%$ of the total daily urine in the pagetic subject and $65 \%$ of the total in the control. Since collagen and gelatin have relatively low absorbance at $280 \mathrm{~m} \mu$ compared to $230 \mathrm{~m} \mu$, these two wavelengths were chosen to scan the eluant fractions. It is seen in Fig. 1 that in the pagetic urine a symmetrical peak, its absorbance monitored at $230 \mathrm{~m} \mu$, contained all of the nondialyzable hydroxyproline. In the normal subject, a trough was seen in the same area and only small amounts of hydroxyproline were found. The rise in absorbance at both 230 and $280 \mathrm{~m} \mu$ at the salt volume of the latter column shown in Fig. 1 was a variable finding seen in both normal and diseased subjects. The fractions containing hydroxyproline were then chromatographed on columns of Bio-Gel P-6. Protein and hydroxyproline emerged in the void volume as shown by the position of marker cytochrome $c$ (mol wt 13,000). 
Portions of the hydroxyproline-polypeptides obtained after filtration on Sephadex G-75 and Bio-Gel P-6 were applied to columns of DEAE-cellulose (Fig. $2 \mathrm{~A}$ ). Before the start of the salt gradient and after elution with $40-50 \mathrm{ml}$ of the starting buffer, two or three peaks with absorbance at $230 \mathrm{~m} \mu$ and containing hydroxyproline were resolved. A large peak emerged following the start of the salt gradient; the front portion of this peak contained hydroxyproline. The hydroxproline-containing fractions were therefore pooled, desalted, and reapplied to similar columns of DEAE-cellulose (Fig. 2 B). The hydroxyproline was then bound to the exchanger until the salt gradient was started and the appropriate fractions collected. The pattern of elution from Sephadex G-75, Bio-Gel P-6, and DEAE-cellulose was similar in samples from all patients whose urine contained enough retentate hydroxyproline to quantitate accurately.

Hydroxyproline polypeptides in the retentate from two patients with Paget's disease also were subjected to cation exchange chromatography on columns of phosphocellulose, after gel filtration on Sephadex G-75 and BioGel P-6. At least 10 different peaks with absorbance at $230 \mathrm{~m} \mu$ were identified (Fig. 3). Each of these contained hydroxyproline, although the larger fore- peaks with the highest absorbance contained the least hydroxyproline.

Composition of the partially purified hydroxyprolinepolypeptides. The amino acid composition of the material obtained from the urine after dialysis and gel filtration resembled that of collagen. In Table I are shown the amino acid compositions of the corresponding peptides purified from the urine of each of two patients with Paget's disease, one with hyperparathyroidism and one with hyperphosphatasia. This fraction was that which emerged from DEAE-cellulose at the start of the salt gradient and was then rechromatographed on DEAE-cellulose. The amino acid composition of each differed from that of human bone gelatin in the absence of 3-hydroxyproline, the relatively high amounts of glutamic and aspartic acids, the relative amounts of lysine and arginine, and the high ratios of 4-hydroxyproline to proline.

The amino acid composition of the fractions eluted from phosphocellulose (Fig. 3) are shown in Table II. All of these had a composition resembling that of collagen except for the early peaks which presumably contained other polypeptides not related to collagen. As would be expected the fractions emerging at the beginning of the

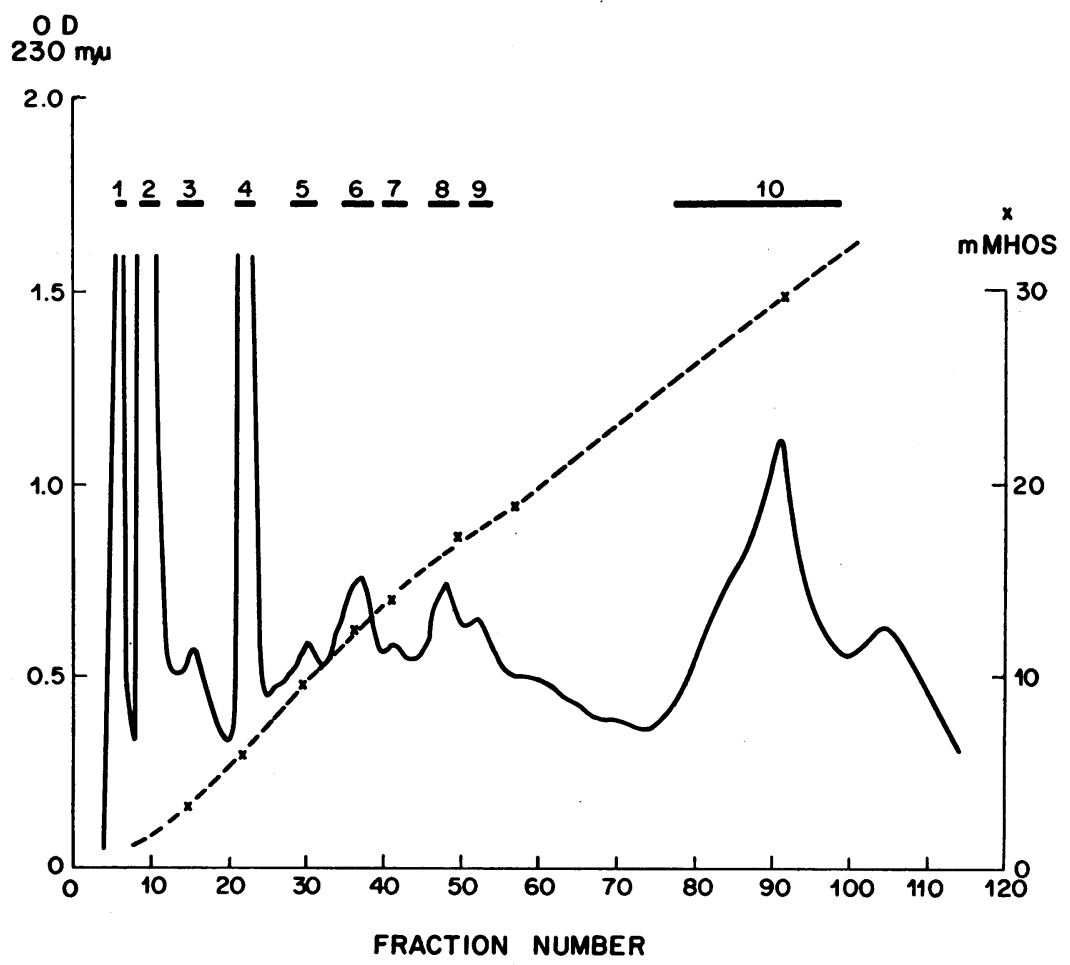

FIGURE 3 Ion exchange chromatography on phosphocellulose of urinary hydroxyproline-containing polypeptides from a patient with Paget's disease (Fig. 1) after initial gel filtration on Sephadex G-75. Dimensions of column were $18 \times 2.5 \mathrm{~cm}$. Each fraction was $10 \mathrm{ml}$. Numbers above bars at top of graph indicate the pooled fractions analyzed in Table II. 
TABLE I

Amino Acid Composition of Urinary Polypeptides Purified by

DEA E-Cellulose Chromatography

\begin{tabular}{|c|c|c|c|c|c|}
\hline \multirow[b]{2}{*}{ Amino acid } & \multicolumn{4}{|c|}{ Peptide* } & \multirow[b]{2}{*}{$\begin{array}{l}\text { Human bone } \\
\text { collagen }\end{array}$} \\
\hline & $\begin{array}{l}\text { Di, Paget's } \\
\text { disease }\end{array}$ & $\begin{array}{l}\text { Sa, Paget's } \\
\text { disease }\end{array}$ & $\begin{array}{c}\text { Ea, hyper- } \\
\text { parathyroidism }\end{array}$ & $\begin{array}{c}\text { Re, hyper- } \\
\text { phosphatasia }\end{array}$ & \\
\hline & \multicolumn{5}{|c|}{ residues $/ 1000$ residues } \\
\hline 3-Hydroxyproline & - & - & - & - & 0.5 \\
\hline 4-Hydroxyproline & 114 & 106 & 111 & 105 & 98 \\
\hline Aspartic acid & 90 & 98 & 89 & 90 & 48 \\
\hline Threonine & 29 & 39 & 35 & 28 & 21 \\
\hline Serine & 50 & 51 & 51 & 51 & 39 \\
\hline Glutamic acid & 89 & 83 & 83 & 83 & 74 \\
\hline Proline & 77 & 93 & 84 & 95 & 116 \\
\hline Glycine & 323 & 285 & 305 & 312 & 317 \\
\hline Alanine & 113 & 114 & 109 & 119 & 112 \\
\hline Cysteine & 0 & 0 & 0 & 0 & 0 \\
\hline Valine & 25 & 23 & 20 & 19 & 23 \\
\hline Methionine & b & $\mathbf{b}$ & b & b & 4 \\
\hline Isoleucine & 4 & 6 & 6 & 3 & 10 \\
\hline Leucine & 6 & 13 & 13 & 6 & 26 \\
\hline Tyrosine & 2 & 3 & 2 & 2 & 4 \\
\hline Phenylalanine & 3 & 6 & 4 & 3 & 14 \\
\hline Hydroxylysine & 5 & 7 & 9 & 6 & 5 \\
\hline Lysine & 44 & 38 & 44 & 48 & 30 \\
\hline Histidine & 4 & 8 & 7 & 4 & 7 \\
\hline Arginine & 21 & 26 & 28 & 25 & 51 \\
\hline
\end{tabular}

$\mathrm{b}=$ small amounts of methionine present but calculation inaccurate because of broadness of peaks.

* Fractions analyzed were those eluted at the beginning of the salt gradient on columns of

DEAE-cellulose, rechromatographed on same column (Fig. 2).

salt gradient had the lowest content of basic amino acids. Cysteine was present in small amounts in several of the fractions.

In all of the amino acid chromatographs of the acid hydrolysates of the urinary polypeptides a ninhydrinpositive peak with absorbance at $570 \mathrm{~m} \mu$ greater than that at $440 \mathrm{~m} \mu$ was observed, which emerged in a position similar to that of standard glucosamine and in close proximity to the position of emergence of valine. Because of this finding carbohydrate analysis was initiated. Several of the polypeptides partially purified after chromatography on DEAE-cellulose contained $0.2-$ $1.4 \mu$ moles glucose equivalent per $\mu$ mole hydroxyproline. The amount of hexosamine estimated by the ElsonMorgan procedure in fractions purified by DEAE column chromatography ranged from 0.4 to $1.0 \mu$ moles glucosamine equivalent per $\mu$ mole hydroxyproline. The purified fraction from patient Sa (Table I) was examined by methanolysis, derivativization, and gas-liquid chromatography. This peptide contained the following carbohydrates: fucose 0.017 , mannose 0.084 , galactose 0.072 , glucose 0.005 , and $N$-acetylglucosamine 0.089 $\mu$ moles per $\mu$ mole amino acid. The quantitation of total amino acid in these samples was performed using the amino acid analyzer.

Other properties of the urinary polypeptides. The mean molecular weight of these polypeptides was estimated to exceed 4500 and be less than 10,000 based on their exclusion from Bio-Gel P-6 and partial retardation on Bio-Gel P-10 in experiments not shown. More accurate determination of molecular weight of one fraction was obtained using high-speed sedimentation equilibrium. The peaks from two subjects shown in Table I ( $\mathrm{Sa}$ with Paget's disease and Ea with hyperparathyroidism) were shown to be largely homogeneous and free from aggregation under the conditions of ultracentrifugation. The values for the number $\left(M_{n}\right)$, weight $\left(M_{*}\right)$, and $z$ average molecular weights as calculated throughout the cell for $\mathrm{Sa}$ (Table I) ranged from 4470 to 4990. Details are given in the Appendix. Similar values were calculated for $\mathrm{Ea}$ (Table I).

Estimation of daily urinary excretion of hydroxyproline polypeptides. The total amounts of polypeptide hydroxyproline excreted daily compared with total hydroxyproline and level of alkaline phosphatase in the serum in different subjects are shown in Table III. 
These values were obtained by determination of hydroxyproline in the fractions emerging from columns of Bio-Gel P-6 containing marker cytochrome $c$.

It has been shown that ingestion of large amounts of gelatin increases the excretion of peptide-bound hydroxyproline in the urine (30). To determine if dietary hydroxyproline could contribute to the polypeptide hydroxyproline one normal male ingested $33 \mathrm{~g}$ of flavored gelatin over a $24 \mathrm{hr}$ period. Total hydroxyproline increased markedly from $19 \mathrm{mg}$ during the $24 \mathrm{hr}$ before ingestion of gelatin to $83 \mathrm{mg}$ during the day the gelatin was consumed. However there was a considerably smaller increase in polypeptide hydroxyproline (from 1.6 to 2.5 $\mathrm{mg} / 24 \mathrm{hr}$ ) indicating that dietary hydroxyproline was not the source of the polypeptide hydroxyproline in this normal subject.

Incorporation of proline ${ }^{11} \mathrm{C}$ into urinary hydroxyproline. As demonstrated previously (9) within an hour of the oral administration of proline $-{ }^{14} \mathrm{C}$ to two subjects with Paget's disease hydroxyproline $-{ }^{14} \mathrm{C}$ was found in the urine. At the peak of labeling, 3-5 hr after the dose, the specific activity of the hydroxyproline ${ }^{14} \mathrm{C}$ in the urine of these two subjects was six and three times higher, respectively, in the retentate than in the diffusate (9). In the present study, an additional patient with extensive active Paget's disease was given $250 \mu \mathrm{Ci}$ proline $-{ }^{14} \mathrm{C}$ orally. The concentration of total activity in the plasma declined rapidly as did the output of ${ }^{14} \mathrm{CO}_{2}$ in expired air (Fig. 4 B). The amount of ${ }^{14} \mathrm{C}$ excreted in the feces was less than $1 \%$ of the administered dose as estimated by combustion analysis (New England $\mathrm{Nu}$ clear Corporation). The specific activity of the urinary retentate hydroxyproline at the time of peak labeling (Fig. 4 A) was three times that of the diffusate hydroxyproline, similar to the other subjects reported previously.

A portion of the urinary retentate collected $2-4 \mathrm{hr}$ after administration of proline ${ }^{-14} \mathrm{C}$ was incubated in $0.02 \mathrm{~m}$ Tris- $\mathrm{HCl}, \mathrm{pH} 7.6,0.001 \mathrm{M} \mathrm{CaCl}$ with $140 \mu \mathrm{g}$ of purified collagenase in total volume of $14.0 \mathrm{ml}$ for $2 \mathrm{hr}$ at $27^{\circ} \mathrm{C}$. A control sample was incubated in buffer alone. Both were then dialyzed for $1 \mathrm{hr}$, the diffusate collected, and the sacs exhaustively dialyzed to remove traces of low molecular weight material. Specific activity of the hydroxyproline ${ }^{-14} \mathrm{C}$ was then determined on all fractions. Before collagenase digestion the specific activity of the diffusate was $56 \mathrm{dpm} / \mu$ mole and that of the retentate $145 \mathrm{dpm} / \mu$ mole. After collagenase the specific activity of the diffusate rose to $124 \mathrm{dpm} / \mu$ mole.

Portions of urine collected from 2 to $10 \mathrm{hr}$ after administration of proline- ${ }^{14} \mathrm{C}$ were pooled, dialyzed, and freeze-dried as described for unlabeled peptides. This

TABLE II

Amino Acid Composition of Urinary Polypeptides Purified by Phosphocellulose Column Chromatography

\begin{tabular}{|c|c|c|c|c|c|c|c|c|c|c|}
\hline \multirow[b]{2}{*}{ Amino acid } & \multicolumn{10}{|c|}{ Peptide* } \\
\hline & 1 & 2 & 3 & 4 & 5 & 6 & 7 & 8 & 9 & 10 \\
\hline & \multicolumn{10}{|c|}{ residues $/ 1000$ residues } \\
\hline Hydroxyproline & 11 & 42 & 113 & 91 & 106 & 111 & 104 & 88 & 134 & 71 \\
\hline Aspartic acid & 176 & 152 & 95 & 118 & 85 & 94 & 83 & 107 & 78 & 113 \\
\hline Threonine & 119 & 101 & 63 & 59 & 34 & 28 & 29 & 17 & 31 & 32 \\
\hline Serine & 84 & 80 & 72 & 77 & 4.3 & 34 & 40 & 28 & 56 & 69 \\
\hline Glutamic acid & 103 & 105 & 87 & 91 & 102 & 83 & 96 & 92 & 90 & 136 \\
\hline Proline & 147 & 142 & 161 & 84 & 101 & 104 & 104 & 83 & 74 & 48 \\
\hline Glycine & 90 & 154 & 245 & 240 & 293 & 312 & 288 & 315 & 317 & 258 \\
\hline Alanine & 78 & 77 & 58 & 121 & 112 & 135 & 124 & 164 & 95 & 85 \\
\hline Cysteine & 6 & 7 & 3 & 0 & 0 & 3 & 5 & 1 & 0 & 12 \\
\hline Valine & b & b & b & b & 30 & 20 & 20 & 14 & 27 & 15 \\
\hline Methionine & 43 & $\mathbf{b}$ & $\mathrm{b}$ & b & b & $\mathrm{b}$ & b & b & $\mathbf{b}$ & 5 \\
\hline Isoleucine & 18 & 19 & 15 & 11 & 6 & 5 & 5 & 4 & 0 & 6 \\
\hline Leucine & 48 & 37 & 21 & 30 & 23 & 9 & 10 & 5 & 2 & 11 \\
\hline Tyrosine & 14 & 19 & 18 & 8 & 6 & 2 & 3 & 2 & 2 & 7 \\
\hline Phenylalanine & 25 & 20 & 12 & 10 & 8 & 3 & 5 & 2 & 2 & 7 \\
\hline Hydroxylysine & 2 & 3 & 2 & 3 & 6 & 6 & 7 & 6 & 8 & 4 \\
\hline Lysine & 15 & 17 & 11 & 26 & 25 & 34 & 50 & 61 & 68 & 37 \\
\hline Histidine & 11 & 11 & 9 & 14 & 5 & 4 & 7 & 4 & 2 & 15 \\
\hline Arginine & 11 & 12 & 14 & 17 & 15 & 12 & 20 & 8 & 14 & 68 \\
\hline
\end{tabular}

$b=$ values uncertain because of broad peaks.

* Fraction analyzed were those eluted from phosphocellulose column numbered as in Fig. 3. 
material was then subjected to gel filtration on columns of Sephadex G-75 in $5 \mathrm{~m} \mathrm{LiCl}$ (Fig. 5). The concentration of the total radioactivity emerging from this column was greatest in those fractions containing hydroxyproline. However the peak of radioactivity was displaced to the left (higher molecular weight) of the peak of hydroxyproline. Therefore specific activities of hydroxyproline $-{ }^{14} \mathrm{C}$ were measured in fractions numbered 35,42 , and 48 and found to be 311,50 , and $27 \mathrm{dpm} /$ $\mu$ mole respectively. The remainder of the fractions containing hydroxyproline were pooled and desalted on columns of Bio-Gel P-6. The polypeptides were then chromatographed on columns of phosphocellulose giving an elution pattern similar to that shown in Fig. 3 (the unlabeled peptides from the same patient). Specific activity of hydroxyproline $-{ }^{1 \mathrm{C}} \mathrm{C}$ was determined on fractions that contained sufficient radioactivity and hydroxyproline; the results are shown in Table IV. The specific activity of all polypeptide fractions was greater than that of the oligopeptide (diffusate) fractions from the same pool. However the difference in one fraction compared to another varied by as much as threefold.

A portion $(50 \mathrm{ml})$ of the urine collected between 10 and $18 \mathrm{hr}$ after administration of proline- ${ }^{14} \mathrm{C}$ was dia-
TABLE III

Polypeptide-Hydroxyproline in Urine

\begin{tabular}{lccc}
\hline \multicolumn{1}{c}{ Subject } & $\begin{array}{c}\text { Alkaline } \\
\text { phosphatase }\end{array}$ & $\begin{array}{c}\text { Total } \\
\text { hypro }\end{array}$ & $\begin{array}{c}\text { Polypeptide } \\
\text { hypro }\end{array}$ \\
\hline & $\begin{array}{c}\text { Bodansky } \\
\text { unils }\end{array}$ & \multicolumn{2}{c}{ mg/24 hr } \\
Bi-normal & 3 & 48 & 1.6 \\
Je-normal & 4 & 34 & 1.5 \\
Mu-normal & 2 & 39 & 1.9 \\
Dr-Paget's disease & 50 & 123 & 5.5 \\
Le-Paget's disease & 27 & 223 & 17.3 \\
Au-Paget's disease & 22 & 322 & 15.4 \\
Cl-Paget's disease & 79 & 325 & 23.3 \\
Di-Paget's disease & 89 & 561 & 25.5 \\
Ma-Paget's disease & 64 & 632 & 28.1 \\
To-Paget's disease & 46 & 980 & 33.3 \\
Wa-Fibrous dysplasia & 35 & 410 & 17.7 \\
\hline
\end{tabular}

lyzed for $1 \mathrm{hr}$ against $150 \mathrm{ml}$ of $\mathrm{H}_{2} \mathrm{O}$ to reduce the amount of salt before concentration. The contents of the sac were then freeze-dried and taken up in $1.0 \mathrm{ml}$ of pyridine $(0.05 \mathrm{M})$-acetic acid $(0.12 \mathrm{~m})$ buffer, $\mathrm{pH} 3.7$, and applied to a column $(100 \times 2.5 \mathrm{~cm})$ of Bio-Gel
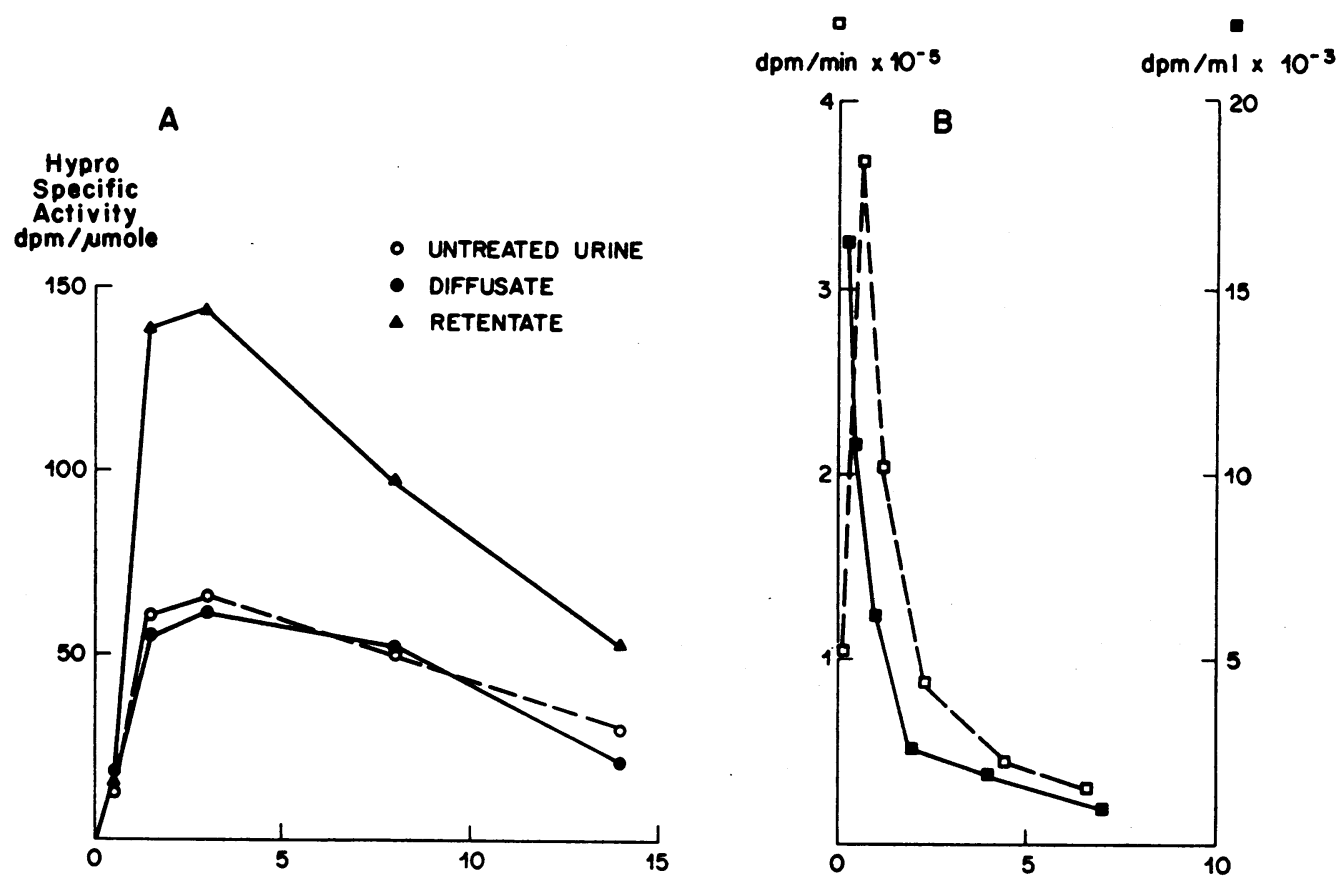

HOURS

FIGURE 4 A. Specific activity of hydroxyproline $-{ }^{14} \mathrm{C}$ in urine as a function of time after administration of proline $-{ }^{14} \mathrm{C}$ to a subject with Paget's disease of bone. $\mathrm{B}$. Total radioactivity in plasma and in expiratory $\mathrm{CO}_{2}$ as a function of time in the same patient. Expired air was collected for periods of $10 \mathrm{~min} .{ }^{14} \mathrm{CO}_{2}$ measured in aliquots and expressed as ${ }^{14} \mathrm{CO}_{2}$ evolved per minute of collection $\left(\mathrm{dpm} / \mathrm{min} \times 10^{-6}\right)$. 


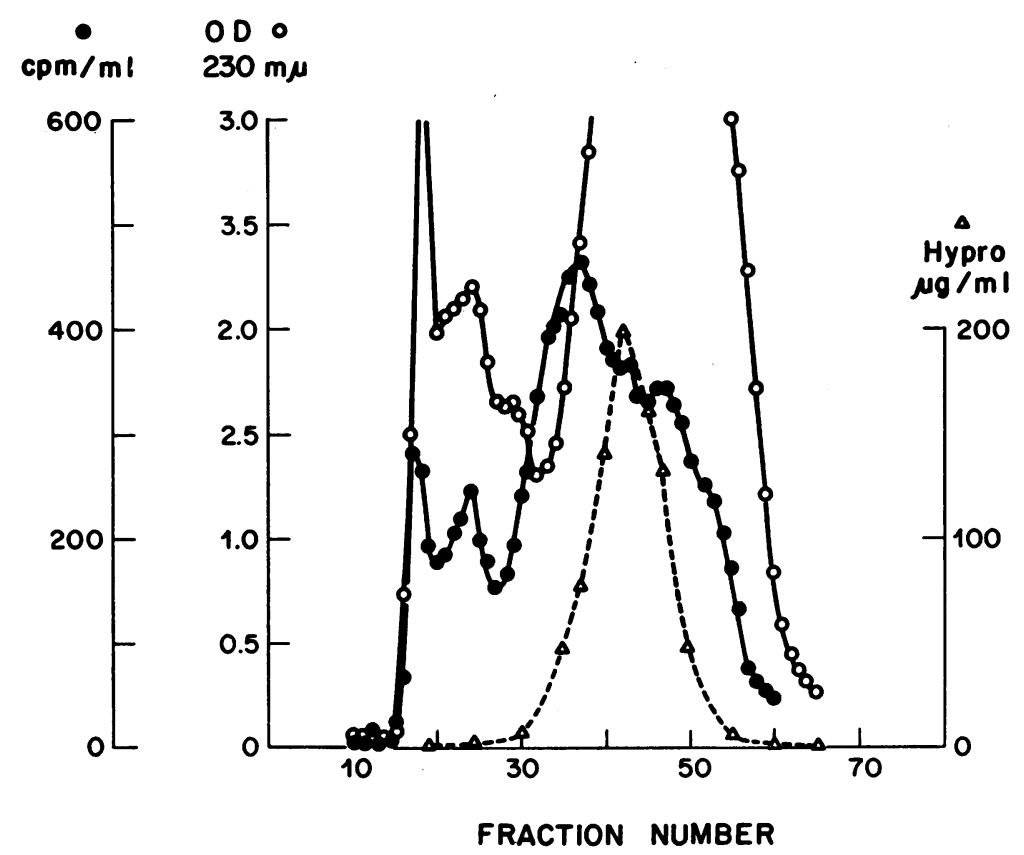

Figure 5 Gel filtration on column of Sephadex G-75 of urinary retentate from a subject with Paget's disease who had been given proline- ${ }^{14} \mathrm{C}$. Portions of urine collected between 2 and $10 \mathrm{hr}$ after administration of proline $-{ }^{14} \mathrm{C}$ were pooled, dialyzed, and freeze-dried before applying to column as described in text. Dimensions of column were $100 \times 2.5 \mathrm{~cm}$. Each fraction was $8 \mathrm{ml}$.

P-6 equilibrated with the same buffer. Fractions were eluted and analyzed for total hydroxyproline and specific activities of hydroxyproline- ${ }^{14} \mathrm{C}$. It is seen in Fig. 6 that the highest specific activities were in the fractions of highest molecular weight and that the specific activity fell rapidly in successive fractions containing the polypeptides. The bulk of the hydroxyproline was of low specific activity, although a distinct rise in specific activity was observed in the fractions eluted in the bed volume of the column.

Excretion of total and polypeptide fractions in patients with hyperparathyroidism. Four patients with hyperparathyroidism were studied before and after removal of a parathyroid adenoma. Hydroxyproline excretion was normalized to creatinine excretion since collections of urine were occasionally incomplete. Comparison of the change in total hydroxyproline and the percentage of retentate/total is seen for one subject in Fig. 7. A three- to fourfold increase in the percentage of retentate/total occurred after removal of the parathyroid adenoma whereas total hydroxyproline fell to less than $20 \%$ of pre-operative levels. The values for all four subjects at a composite are shown in Fig. 8. In all subjects the absolute amount of polypeptide hydroxyproline decreased after parathyroidectomy. However, since the percentage fall was less than that of the
TABLE IV

Specific Activity of Hydroxyproline-14C in Fractions Eluted from Phosphocellulose Columns

\begin{tabular}{cc}
\hline Sample* & $\begin{array}{c}\text { Hydroxyproline-14C } \\
\text { specific activity }\end{array}$ \\
\hline & $d p m / \mu m o l e$ \\
Untreated urine & 46 \\
Urine after dialysis & 90 \\
Retentate & 31 \\
Diffusate & \\
Fractions after phosphocellulose & \\
3 & 60 \\
4 & 58 \\
5 & 134 \\
6 & 97 \\
7 & 81 \\
8 & 49 \\
9 & 42 \\
$10 \mathrm{a}$ & 83 \\
$10 \mathrm{~b}$ & 57 \\
\hline
\end{tabular}

* Pooled urine containing aliquot portions from samples collected up to $10 \mathrm{hr}$ after administration of proline-14C to patient with Paget's disease.

‡ Samples correspond to those in Fig. 3. Fraction No. 10 was divided for the analysis of specific activity. 


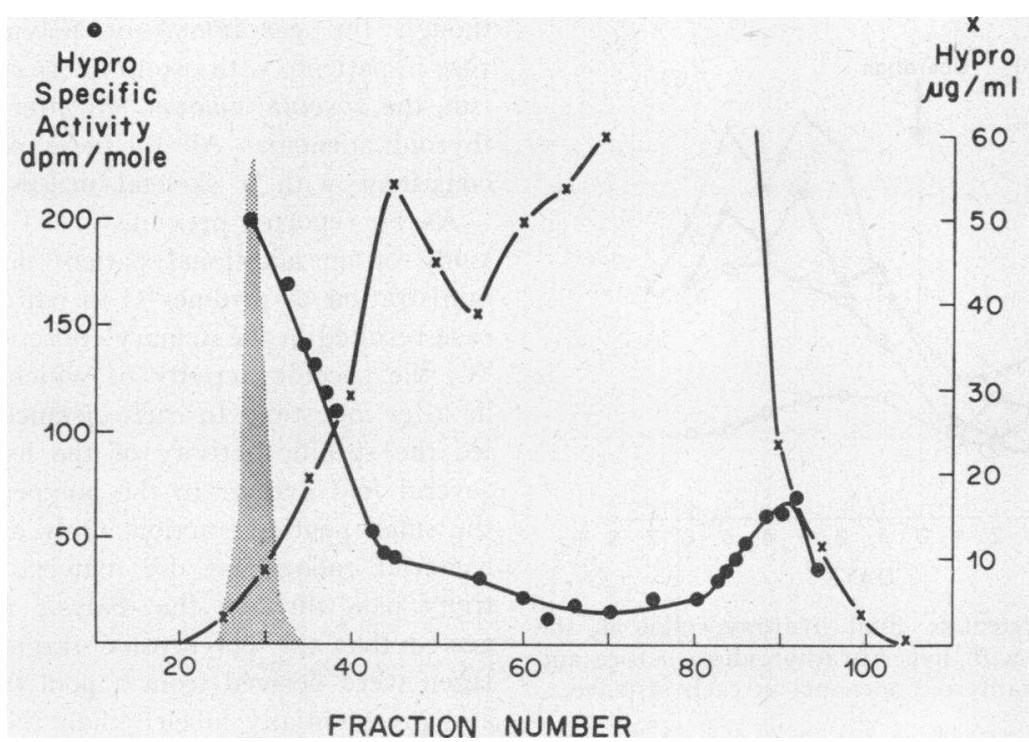

Figure 6 Gel filtration on column of Bio-Gel P-6 of urine from the same subject with Paget's disease as in Fig. 5. Sample was a portion of that collected between 10 and $18 \mathrm{hr}$ after administration of proline- ${ }^{14} \mathrm{C}$. Dimensions of column were $100 \times 2.5 \mathrm{~cm}$. Each fraction was $5 \mathrm{ml}$. Shaded area indicates position of emergence of cytochrome $c$ used as marker.

total, the relative amount of polypeptide hydroxyproline rose. The rise in the retentate fraction was minimal in the one patient who had no evidence of subperiosteal resorption.

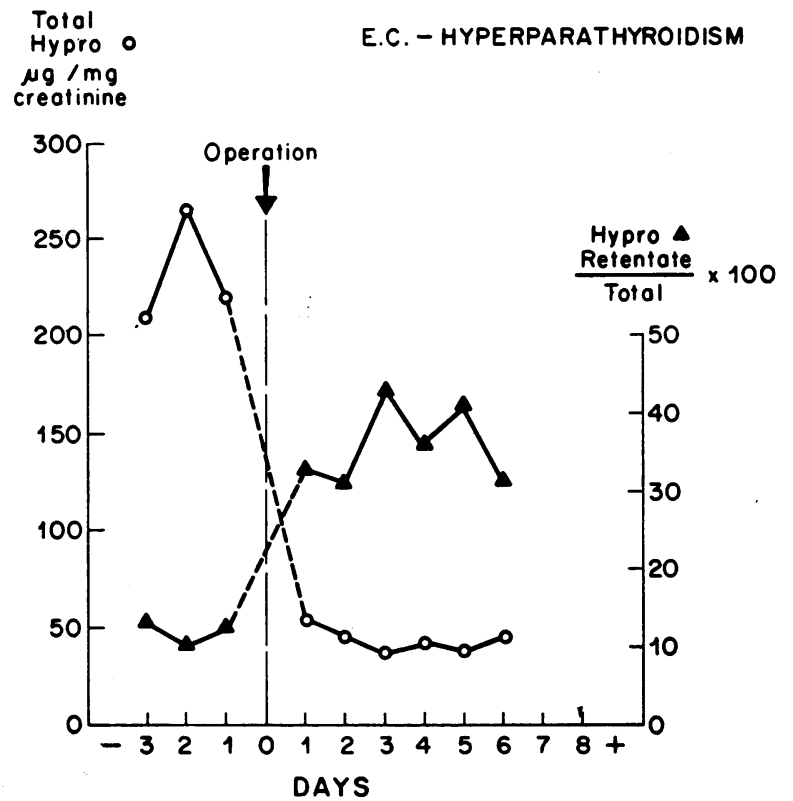

Figure 7 Urinary excretion of total hydroxyproline and the ratio of retentate: total hydroxyproline in a patient with hyperparathyroidism before and after removal of a single parathyroid adenoma.

\section{DISCUSSION}

Although most of the urinary hydroxyproline is present in the form of low molecular weight peptides which are readily dialyzable, a small but reproducible portion is in the form of higher molecular weight material. Because the total urinary excretion of hydroxyproline is so high in some patients with metabolic bone disease it is possible to isolate enough of these polypeptides to characterize partially their structure. The data presented in this report support the idea that this material is related to collagen. Amino acid composition of the partially purified polypeptides resembles that of collagen not only in the content of hydroxyproline but also in the presence of hydroxylysine, the high content of glycine and alanine, and the low content of tyrosine and cysteine. The ultraviolet absorption spectra (9) are also consistent with the amino acid composition.

Since the molecular weight of the polypeptides that have been measured is only a fraction of that of the $\alpha$-chain of the collagen molecule (5000 compared with 100,000 ), it is not surprising that the amino acid composition of these polypeptides differs from whole $\alpha$-chains. Although glycine is quite regularly distributed throughout the collagen molecule, occurring every third residue, and proline and hydroxyproline are also evenly spaced, the distribution of the acidic and basic amino acids is such that their concentration is often highest in regions which are relatively poor in hydroxyproline (31). Ratios of hydroxyproline: proline greater than one, as were 


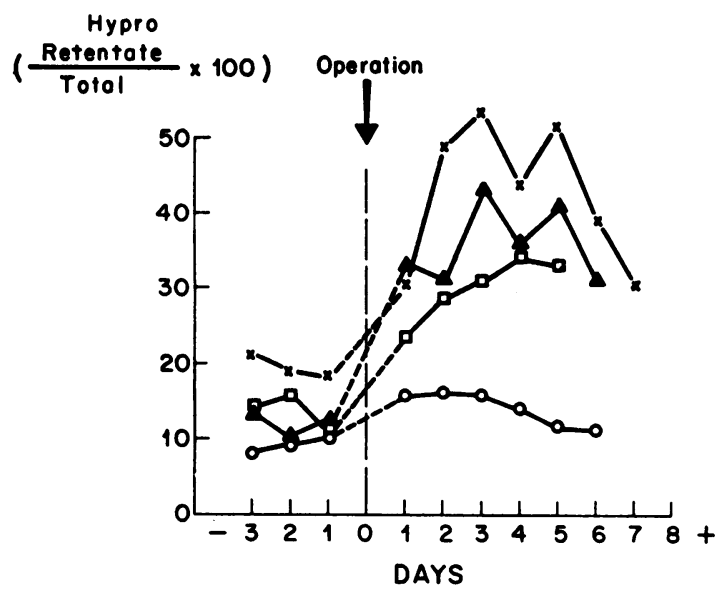

FIGURE 8 Ratio of retentate: total hydroxyproline in the urine of four patients with hyperparathyroidism before and after removal of a parathyroid adenoma in each instance.

found in the urinary polypeptides, are unusual for collagen, since only the second proline in the sequence -Gly-Pro-Pro- can be hydroxylated in vertebrate collagens (32). However, amino acids other than proline can be found adjacent to glycine. The susceptibility of the urinary polypeptides to cleavage by purified clostridial collagenase (9) is evidence that the sequence -Pro-XGly-Pro-Y- (33) is present in the polypeptides and is consistent with the high content of glycine and the imino acids.

Preliminary assays have shown the presence of glucosamine and a high content of neutral sugar, unusual for mammalian collagens except for vitrosin from the eye (34). The small amount of hexose present in most collagens is largely in the form of glucosyl-galactosylhydroxylysine (35). No hexosamine is present in bone or skin collagens although some may be present in the glomerular basement membranes (36). Since it is presumed that the urinary polypeptides have their origin in bone (see further discussion below) the carbohydrate composition is unexplained. It should be noted however that glycopeptides containing hydroxyproline have been identified previously in human urine $(10,11)$.

Although the percentage of the total hydroxyproline in the retentate fraction after dialysis did not differ significantly in the urine from normals compared to patients with Paget's disease, the total retentate hydroxyproline was considerably less in the normals. The total amount of urinary hydroxyproline is usually directly proportional to the extent and activity of the Paget's disease as measured by radiocalcium kinetics (13). The breakdown of dietary gelatin did not contribute significantly to the polypeptide hydroxyproline as it did to low molecular weight hydroxyproline peptides. Al- though the percentage of polypeptide-hydroxyproline rose in patients with osteitis fibrosa of hyperparathyroidism, the absolute amount fell after removal of the parathyroid adenoma. All of these observations are most consistent with a skeletal origin of the polypeptides.

As we reported previously (9) and confirmed by the study of an additional patient detailed here, oral administration of proline $-{ }^{14} \mathrm{C}$ to patients with Paget's disease resulted in the urinary excretion of hydroxyproline${ }^{14} \mathrm{C}$, the specific activity of which reached a peak $2-4$ $\mathrm{hr}$ after ingestion. In each instance at all intervals studied the specific activity of the hydroxyproline $-{ }^{14} \mathrm{C}$ was several fold greater in the polypeptide fraction than in the small peptide fraction. Only after degradation with bacterial collagenase did material of high specific activity pass through the dialysis membrane. This suggested that the polypeptide fragments resembling collagen were derived from a pool that was more rapidly and preferentially labeled than the bulk of the urinary hydroxyproline. However, the polypeptide material was not uniformly labeled but consisted of a group of peptides of variable molecular weights and specific activities. Our evidence suggests that the material excreted of the highest molecular weight is the most recently synthesized. The rapid fall in specific activity across the polypeptide peak on gel filtration suggests that the hydroxyproline from less highly labeled collagen must contribute to some extent to the polypeptide fraction.

The results of the isotope incorporation studies suggested that the polypeptides containing hydroxyproline and resembling fragments of collagen were somehow related to collagen synthesis. We turned to studies of hyperparathyroid patients to examine the problem in a different way (37). In hyperparathyroidism with osteitis fibrosa, bone formation and resorption are both occurring at increased rates. After surgical treatment of the hyperparathyroidism, bone destruction decreases whereas bone formation continues at a high rate during the period of repair. The abrupt decrease in urinary excretion of total hydroxyproline has been interpreted as an indication of the decrease in bone resorption and collagen degradation (38). We reasoned that during this initial period after parathyroidectomy, a fall in bone resorption greater than in formation would result in a relative increase in the excretion of polypeptide-hydroxyproline if this fraction were related to collagen synthesis. This increase in the ratio of polypeptide hydroxyproline to total hydroxyproline after the removal of a parathyroid adenoma was observed in each case. Observations by others in patients with acromegaly and thyrotoxicosis also support the hypothesis that the excretion of the polypeptide fragments containing hydroxyproline correlates directly with bone formation (39). 
With regard to the size of the urinary polypeptides, the particular fractions examined in the ultracentrifuge by sedimentation equilibrium had molecular weights calculated to be approximately 5000 . However, it is likely from the pattern of elution on gel filtration and from the amino acid composition that some of these peptides are larger than 5000 but probably smaller than 10,000 molecular weight. The polypeptides do not readily pass dialysis sacs with diameter of $9 / 16$ inch as might be expected for materials of this size (40). However, the failure to pass through the pores in these membranes may reflect the probability that these fragments, like collagen itself, are not globular in shape. Based on the data obtained by optical rotatory dispersion (9) the polypeptides probably interact with themselves or other chains at the low temperatures at which dialysis was carried out producing larger solute particles. It has been reported that other urinary peptides of molecular weight range 5000-10,000 not containing hydroxyproline readily pass through dialysis membranes (41).

There are several ways in which these collagenlike fragments could appear in the urine so soon after synthesis. We postulated previously (9) that they might represent synthetic subunits (42) of the $\alpha$-chains. There is no new evidence to support this possibility. Alternatively these polypeptides could arise from the selective degradation of newly synthesized collagen. In this regard Lapiere, Onkelinx, and Richelle (43) in studies of rat bone have found that a large fraction of the newly synthesized hydroxyproline does not appear in the fully mature calcified matrix. Whatever their source, the rate of excretion as well as the relative proportion of these collagen-like fragments may serve as an index of collagen synthesis in normal and diseased subjects.

\section{APPENDIX}

Determination of molecular weight. Molecular weights were estimated by high-speed equilibrium sedimentation (23) using the Rayleigh optical system of a Beckman model $\mathrm{E}$ analytical ultracentrifuge. Measurements of molecular weights were performed by Dr. Michael Young who made available to us the Fortran IV program of Roark and Yphantis. Solute was fully equilibrated with solvent $(0.1 \mathrm{M}$ Tris- $\mathrm{HCl}, \mathrm{pH} 7.6)$ by dialysis and then placed in one channel of a double sector cell equipped with sapphire windows. An equal volume of undialyzed solvent was placed in the companion sector to insure equal levels in sample and reference chambers. After attainment of sedimentation equilibrium (usually $24 \mathrm{hr}$ ) photographs were taken with spectroscopic Type II G plates and measured with a two dimensional microcomparator (Nikon, model 6). Number $\left(M_{n}\right)$, weight $\left(M_{\infty}\right)$, and $z\left(M_{\varepsilon}\right)$ average molecular weight moments were calculated throughout the cell from the following expressions, where $x=$ radius of rotation; $\mathrm{c}=$ concentration: $\varphi=$ apparent partial specific volume; and $\mathrm{m}$ refers to the rotation radius of the meniscus.

$$
\begin{aligned}
& \mathrm{M}_{n}(x)=\frac{\mathrm{RT}}{\frac{\mathrm{c}(x)}{(1-\phi \rho) \omega^{2}} \cdot \int_{x_{m}}^{x} x \mathrm{c}(x) \mathrm{d} x+\frac{\mathrm{c}(\mathrm{m})}{\mathrm{M}_{n}(\mathrm{~m})}} \\
& \mathrm{M}_{w}(x)=\frac{2 \mathrm{RT}}{(1-\phi \rho) \omega^{2}} \cdot \frac{\mathrm{d} \ln \mathrm{c}(x)}{\mathrm{d}\left(x^{2}\right)} \\
& \mathrm{M}_{z}(x)=\frac{\mathrm{RT}}{(1-\phi \rho) \omega^{2}} \cdot \frac{\mathrm{d}^{2} \mathrm{c}(x) / \mathrm{d}\left(\frac{x^{2}}{2}\right)}{\mathrm{dc}(x) / \mathrm{d}\left(\frac{x^{2}}{2}\right)}
\end{aligned}
$$

All data were calculated by a Fortran IV program and an IBM-360 computer. It should be recognized that even at 60,000 rpm the concentrations of peptides used in this study were not negligible at the solvent meniscus and thus $\frac{c(m)}{M_{n}(m)}$ in equation 1. did not vanish.

The program takes account of this feature and calculates $\frac{c(m)}{M_{n}(m)}$ from a linear combination of $M_{w}$ and $M_{z}$ according to the expression

$$
\mathrm{M}_{n}(\mathrm{~m})=\frac{3}{2} \mathrm{M}_{w}(\mathrm{~m})-\frac{1}{2} \mathrm{M}_{\mathbf{z}}(\mathrm{m})
$$

The values for number $\left(M_{n}\right)$, weight $\left(M_{w}\right)$, and $z\left(M_{z}\right)$ average molecular weights calculated throughout the cell are shown in Table V.

TABLE V

Number, Weight, and z Average Molecular Weights of Urinary Polypeptide as a Function of Solute Concentration*

\begin{tabular}{cccc} 
& \multicolumn{3}{c}{ Molecular weight } \\
\cline { 2 - 4 } Concn $\ddagger$ & $\mathrm{M}_{n}$ & $\mathrm{M}_{w}$ & $\mathrm{M}_{z}$ \\
\hline$m m$ & & & \\
0.104 & 4470 & 4490 & 4510 \\
0.128 & 4490 & 4490 & 4530 \\
0.158 & 4490 & 4510 & 4550 \\
0.197 & 4490 & 4490 & 4550 \\
0.242 & 4490 & 4490 & 4570 \\
0.297 & 4490 & 4510 & 4610 \\
0.367 & 4490 & 4550 & 4740 \\
0.457 & 4530 & 4700 & 4990 \\
0.571 & 4550 & 4740 & 4930 \\
0.715 & 4590 & 4700 & 4720 \\
0.889 & 4610 & 4720 & 4740 \\
1.109 & 4630 & 4720 & 4740 \\
\hline
\end{tabular}

* Peptide analyzed was that purified by DEAE column chromatography (Sa, Table I). Conditions were as follows: rotor velocity $=60,000 \mathrm{rpm}$; temperature $=22.4^{\circ} \mathrm{C}$ solution column height $=2.8 \mathrm{~mm}$; initial peptide concentration $=$ approx. $0.25 \mathrm{mg} / \mathrm{ml} ; \phi$ assumed to be $0.70 \mathrm{ml} / \mathrm{g}$, based on reported values for denatured collagen (44).

‡ Concentrations refer to $\mathrm{mm}$ vertical fringe displacements. They have been estimated from the raw data by the computer program. 


\section{ACKNOWLEDGMENTS}

We acknowledge the expert technical assistance of Mrs. Kathleen Grant. Additional technical assistance was provided by $\mathrm{Mr}$. Joseph $\mathrm{M}$. Bianchi and Mrs. Emma Taylor. We thank Doctors Melvin J. Glimcher and Sheldon R. Pinnell for some of the amino acid analyses, Doctors Roger W. Jeanloz and Vernon Reinhold for gas chromatography of carbohydrates and Doctors Andrew Kang, Marvin L. Tanzer, and Michael Young for helpful advice. We thank Doctors Oliver Cope and Chiu-An Wang for permission to study their patients with hyperparathyroidism and Doctors Gerald E. Gaull and Roby C. Thompson, Jr., for the samples from their patient with hyperphosphatasia. We thank Mrs. Bivian Marr, Head Nurse, and Miss Petrina Mandella, Dietician, and their staffs of the Metabolic Ward for their cooperation. We also thank Mrs. Walda M. Giallongo and Mrs. Barbara Wagner for preparation of the manuscript.

This work was supported by U. S. Public Health Service Research Grants AM-3564 and AM-4501 and Training Grant AM-5067. This is publication No. 493 of the Robert W. Lovett Memorial Group for the Study of Diseases Causing Deformities.

\section{REFERENCES}

1. Eastoe, J. E. 1967. Composition of collagen and allied proteins. In Treatise on Collagen. Vol. I. G. N. Ramachandran, editor. Academic Press Inc., New York. 1.

2. Neuberger, A., and F. F. Richards. 1963. Protein biosynthesis in mammalian tissues. II. Studies on turnover in the whole animal. In Mammalian Protein Metabolism. Vol. 1. H. N. Munro and J. B. Allison, editors. Academic Press Inc., New York. 243.

3. Prockop, D. J., and K. I. Kivirikko. 1967. Relationship of hydroxyproline excretion in urine to collagen metabolism. Ann. Intern. Med. 66: 1243.

4. Dubovsky, J., J. Formankova, and E. Dubovska. 1964. Hydroxylyzin $\mathbf{v}$ moci $\mathbf{u}$ osteopatii s vysokym obratem kostni matrix. Cas. Lék. Ces. 103: 187.

5. Nagant de Deuxchaisnes, C., and S. M. Krane. 1967. The treatment of adult phosphate diabetes and Fanconi syndrome with neutral sodium phosphate. Amer. J. Med. 43: 508 .

6. Lindstedt, S., and D. J. Prockop. 1961. Isotope studies on urinary hydroxyproline as evidence for rapidly catabolized forms of collagen in the young rat. J. Biol. Chem. 236: 1399.

7. Prockop, D. J. 1964. Isotopic studies on collagen degradation and the urine excretion of hydroxyproline. J. Clin. Invest. $43: 453$.

8. Meilman, E., M. M. Urivetzky, and C. M. Rapoport. 1963. Urinary hydroxyproline peptides. J. Clin. Invest. $42: 40$.

9. Krane, S. M., A. J. Muñoz, and E. D. Harris, Jr. 1967. Collagen-like fragments: excretion in urine of patients with Paget's disease of bone. Science (Washington). $157: 713$.

10. Bourrillon, R., and J. L. Vernay. 1966. Deux glycopeptides a hydroxyproline dans l'urine humaine normale. Biochim. Biophys. Acta. 117: 319.

11. Cherian, M. G., and A. N. Radhakrishnan. 1966. Isolation and characterization of a new glycopeptide containing hydroxyproline from human urine. Indian J. Biochem. $3: 101$.
12. Dull, T. A., and P. H. Henneman. 1963. Urinary hydroxyproline as an index of collagen turnover in bone. N. Engl.J. Med. 268: 132.

13. Nagant de Deuxchaisnes, C., and S. M. Krane. 1964. Paget's disease of bone: clinical and metabolic observations. Medicine. 43: 233.

14. Thompson, R. C., Jr., G. E. Gaull, S. J. Horwitz, and R. K. Schenk. 1969. Hereditary hyperphosphatasia. Studies of three siblings. Amer. J. Med. 47: 209.

15. Prockop, D. J., and S. Udenfriend. 1960. A specific method for the analysis of hydroxyproline in tissues and urine. Anal. Biochem. $1: 228$.

16. Bergman, I., and R. Loxley. 1963. Two improved and simplified methods for the spectrophotometric determination of hydroxyproline. Anal. Chem. 35: 1961.

17. Piez, K. A., and L. Morris. 1960. A modified procedure for the automatic analysis of amino acids. Anal. Biochem. 1: 187 .

18. Lowry, O. H., N. J. Rosebrough, A. L. Farr, and R. J. Randall. 1951. Protein measurement with the Folin phenol reagent. J. Biol. Chem. 193: 265.

19. Seifter, S., P. M. Gallop, L. Klein, and E. Meilman. 1959. Studies on collagen. II. Properties of purified collagenase and its inhibition. J. Biol. Chem. 234: 285.

20. Spiro, R. G. 1960. Studies on fetuin, a glycoprotein of fetal serum. I. Isolation, chemical composition, and physiochemical properties. J. Biol. Chem. 235: 2860.

21. Park, J. T., and M. J. Johnson. 1949. A submicrodetermination of glucose. J. Biol. Chem. 181: 149.

22. Neuberger, A., and R. D. Marshall. 1966. Methods for the qualitative and quantitative analysis of the component sugars. In Glycoproteins their Composition, Structure and Function. A. Gottschalk, editor. Elsevier, Amsterdam. 190.

23. Yphantis, D. A. 1964. Equilibrium ultracentrifugation of dilute solutions. Biochemistry. 3: 297.

24. Bello, J., H. C. A. Riese, and J. R. Vinograd. 1956. Mechanism of gelation of gelatin. Influence of certain electrolytes on the melting points of gels of gelatin and chemically modified gelatins. J. Phys. Chem. 60: 1299 .

25. Kang, A. H., K. A. Piez, and J. Gross. 1969. Characterization of the cyanogen bromide peptides from the $\alpha 1$ chain of chick skin collagen. Biochemistry. 8: 1506.

26. LeRoy, E. C., E. D. Harris, Jr., and A. Sjoerdsma. 1966. A modified procedure for radioactive hydroxyproline assay in urine and tissues after labeled proline administration. Anal. Biochem. 17: 377.

27. Juva, K., and D. J. Prockop. 1966. Modified procedure for the assay of $\mathrm{H}^{3}$ - or $\mathrm{C}^{14}$-labeled hydroxyproline. Anal. Biochem. 15 : 77.

28. Bray, G. A. 1960. A simple efficient liquid scintillator for counting aqueous solutions in a liquid scintillation counter. Anal. Biochem. 1: 279.

29. Rabkin, M. T., E. W. Frederick, M. Lotz, and L. H. Smith, Jr. 1962. Pyrimidine metabolism in man. V. The measurement in vivo of the biochemical effect of antineoplastic agents in animal and human subjects. J. Clin. Invest. 41: 871.

30. Prockop, D. J., and A. Sjoerdsma. 1961. Significance of urinary hydroxyproline in man. J. Clin. Invest. 40: 843.

31. Hannig, K., and A. Nordwig. 1967. Amino acid sequences in collagen. In Treatise on Collagen. Vol. 1. G. N. Ramachandran, editor. Academic Press Inc., New York. 73.

32. Kivirikko, K. I., and D. J. Prockop. 1967. Purification and partial characterization of the enzyme for the hydroxy- 
lation of proline in protocollagen. Arch. Biochem. Biophys. 118: 611 .

33. Seifter, S., and P. M. Gallop. 1966. The structure proteins. In The Proteins. Vol. IV. H. Neurath, editor. Academic Press Inc., New York. 153.

34. Matotsy, A. G. 1952. A study on the structural protein of the vitreous body (vitrosin). J. Gen. Physiol. 36: 29.

35. Butler, W. T., and L. W. Cunningham. 1966. Evidence for the linkage of a disaccharide to hydroxylysine in tropocollagen. J. Biol. Chem. 241: 3882.

36. Spiro, R. G. 1967. Studies on the renal glomerular basement membrane. Nature of the carbohydrate units and their attachment to the peptide portion. J. Biol. Chem. 242: 1923.

37. Harris, E. D., Jr., and S. M. Krane. 1968. Urinary polypeptides related to collagen synthesis. Clin. Res. 16: 551. (Abstr.)

38. Laitinen, O., E. A. Nikkilä, and K. I. Kivirikko. 1966. Hydroxyproline in the serum and urine. Normal values and clinical significance. Acta Med. Scand. 179: 275.
39. Haddad, J., S. Birge, S. Couranz, and L. V. Avioli. 1969. Non-dialyzable urinary hydroxyproline: an index of bone formation? Clin. Res. 17: 285. (Abstr.)

40. Craig, L. C., and T. P. King. 1962. Dialysis. In Methods of Biochemical Analysis, Vol. X. D. Glick, editor. Interscience Publishers Inc., New York. 175.

41. Rudman, D., A. del Rio, S. Akgun, and E. Frumin. 1969. Novel proteins and peptides in the urine of patients with advanced neoplastic disease. Amer. J. Med. 46: 174.

42. Blumenfeld, O. O., M. Rojkind, and P. M. Gallop. 1965. Subunits of hydroxylamine-treated tropocollagen. Biochemistry. $4: 1780$.

43. Lapiere, C. M., C. Onkelinx, and L. J. Richelle. 1966. Collagen metabolism in skin and bone. In Biochemie et physiologie du tissue conjonctif. P. Comte, editor. Société Ormeco et Imprimerie du Sud-Est à Lyon. 505 .

44. Piez, K. A. 1967. Soluble collagen and the components resulting from its denaturation. In Treatise on Collagen, Vol. 1. G. N. Ramachandran, editor. Academic Press Inc., New York. 207. 